\title{
IMPLEMENTASI MANAJEMEN PENDIDIKAN SEKOLAH BERBASIS BOARDING DALAM MENINGKATKAN MUTU PENDIDIKAN DI AL- WILDAN ISLAMIC BOARDING SCHOOL TANGERANG
}

\author{
Rizka Fitria \\ UIN Antasari Banjarmasin \\ $\underline{\text { Rizkafitriaaa351@gmail.com }}$
}

\begin{abstract}
This study wanted to describe school management during completion and completion at $\mathrm{Al}$ Wildan Islamic Boarding School. This type of qualitative research with descriptive methods. The research objects are the Principal and Director of Education, the curriculum section, the personnel section, the infrastructure section, the student body section, the public relations section, the finance section, and the administration section. Researchers used methods of observation, interviews, and documentation. Data data in the form of data data. The method of data analysis includes 14 activities: first, data collection and data reduction, Second, data in the form of narrative. Third, the withdrawal of conclusions. The results of the research shown Al Wildan boarding school has not been put to good use. The integration is seen in activity programs and learning programs. Management here is categorized into 7 types namely: curriculum management, personnel, students, infrastructure, finance, public relations, and special services. So, between the management in the school and in boarding are interrelated. Furthermore, according to the results of a study done at Tangerang Al Wildan Islamic Boarding School using TQM techniques. The TQM that has been implemented is running well. This is evidenced through an explanation of the terms of the TQM implementation that has been included. As a commitment of the principal, have the vision, mission, and goals of the school, benefit from its success, have published influence, and a board of directors.
\end{abstract}

Keyword: boarding, management, education, TQM

\begin{abstract}
ABSTRAK
Penelitian ini bertujuan untuk menggambarkan pelaksanaan manajemen sekolah berbasis boarding dan peningkatan mutu di Al Wildan Islamic Boarding School. Jenis penelitian berbentuk kualitatif dengan metode deskriptif. Obyek penelitiannya yaitu Kepala Sekolah dan Direktur Pendidikan, bagian kurikulum, bagian kepegawaian, bagian sarana prasarana, bagian kesiswaan, bagian humas, bagian keuangan, dan bagian ketatausahaan. Peneliti menggunakan metode observasi, interview, dan dokumentasi. Sumber data berupa data primer. Metode menganalisis data terdiri dari 14 kegiatan: pertama, pengumpulan data dan melakukan reduksi data, Kedua, data disajikan dalam bentuk narasi. Ketiga, penarikan kesimpulan. Hasil penelitian menunjukkan bahwa penerapan manajemen sekolah berbasis boarding di $\mathrm{Al}$ Wildan Islamic Boarding School Tangerang sudah berjalan dengan baik. Perpaduannya terlihat pada program kegiatan dan program pembelajaran. Manajemen di sini dikategorikan menjadi 7 macam yaitu: manajemen kurikulum, kepegawaian, kesiswaan, sarana prasarana, keuangan, humas, dan layanan khusus. Jadi, antara manajemen di sekolah dengan di boarding
\end{abstract}


saling berkaitan. Selanjutnya, berdasarkan hasil penelitian peningkatan mutu di Al Wildan Islamic Boarding School menggunakan teknik TQM. TQM yang diterapkan sudah berjalan dengan baik. Hal tersebut terbukti melalui penjabaran pada syarat-syarat pelaksanaan TQM yang sudah terpenuhi. Seperti komitmen dari kepala sekolah, adanya visi, misi, dan tujuan sekolah, adanya perbaikan secara berkesinambungan, adanya pendekatan publisitas, dan Steering committee.

Kata kunci: boarding, manajemen, pendidikan, TQM

\section{PENDAHULUAN}

Pendidikan adalah usaha sadar dan terencana untuk mewujudkan suasana belajar dan proses pembelajaran agar peserta didik secara aktif mampu mengembangkan potensi dirinya serta memiliki kekuatan spiritual keagamaan, pengendalian diri, kecerdasan, akhlak mulia, dan keterampilan (Tim Penyusun UU Sisdiknas, 2003).

Bekal pendidikan sejak dini baik secara formal, informal, maupun non formal menjadi tumpuan untuk melahirkan manusia baru dengan karakter yang kuat. Adapun karakter kuat ini dicirikan oleh kapasitas moral seseorang seperti, kejujuran, kekhasan kualitas seseorang yang membedakan dirinya dari orang lain, dan ketegaran menghadapi kesulitan (Suhardi, 2012).

Karakter bangsa yang kuat bisa diperoleh dari sistem pendidikan yang tidak hanya mementingkan kecerdasan intelektual semata, melainkan juga kecerdasan spiritual. Sekolah formal adalah contoh lembaga pendidikan yang menekankan pencapaian prestasi anak didik dalam hal kecerdasan intelektual dan bermuara pada berbagai ukuran akademik. Sementara itu, boarding menjadi salah satu lembaga pendidikan yang mengutamakan pencapaian kecerdasan spiritual.

Pesantren ataupun saat ini kita kenal dengan istilah Boarding merupakan institusi pendidikan Islam asli dan tertua di Indonesia yang telah turut membina dan mengembangkan sumber daya manusia untuk mencapai keunggulan (excellence). Boarding telah berperan besar dalam upaya meningkatkan kecerdasan dan martabat manusia (Siradj, 1999).

Secara umum, sekolah dan boarding merupakan dua lembaga pendidikan yang memiliki keunggulan masing-masing. Apabila keunggulan dari kedua lembaga pendidikan itu dipadukan, maka akan tercipta sebuah kekuatan pendidikan yang mampu menghasilkan generasi muda yang cerdas dan berkarakter baik. Sekolah berbasis boarding dianggap mampu mencetak anak didik yang berpengetahuan umum serta mempunyai kepribadian religius, sederhana, dan mandiri.

Sekolah berbasis boarding merupakan model pendidikan yang mengintegrasikan berbagai kecerdasan sebagai upaya pembentukan multiple intelegence peserta didik agar memiliki kemampuan intelektual (fikr), kemampuan moralitas (zikr dan qalb), dan kemampuan untuk melakukan sesuatu atas dasar keterampilan (amal) serta profesionalitas (Purwoko, 2021).

Sekolah berbasis boarding merupakan salah satu alternatif untuk mengembalikan karakter bangsa yang mulai luntur di tengah arus globalisasi dan modernisasi seperti sekarang ini. Anak didik yang hanya dijejali pendidikan dunia saja dikhawatirkan akan melahirkan generasi buruk. Sekolah berbasis boarding diharapkan dapat memberikan kontribusi positif dalam rangka mengurangi arus moral remaja yang semakin menyimpang. 
Saat ini, sekolah berbasis boarding menjadi salah satu lembaga pendidikan yang banyak diminati oleh berbagai kalangan karena dianggap mampu memberikan bekal dasardasar keagamaan yang cukup sekaligus mampu menjadikan peserta didik tampil cakap di dunia modern. Sekolah berbasis boarding telah diprogramkan pemerintah secara terus menerus sebagai upaya untuk meningkatkan mutu pendidikan dan mampu memenuhi kebutuhan kualitas lulusan. Banyak lulusan yang tidak siap untuk menjadi warga negara yang bertanggung jawab dan tidak produktif. Lulusan tersebut adalah produk sistem pendidikan yang tidak terfokus pada mutu.

Untuk itu, Direktorat Pembinaan Sekolah bertanggung jawab terhadap pemenuhan aspek-aspek peningkatan mutu sekolah dan Direktorat Pendidikan Boarding bertanggung jawab terhadap pemenuhan aspek-aspek peningkatan mutu boarding. Dari paparan di atas, penulis melakukan penelitian di sebuah sekolah formal yang berbasis boarding dalam setiap pelaksanaan program pendidikannya. Objek penelitian dilaksanakan di Al Wildan Islamic Boarding School Tangerang.

Al Wildan Islamic Boarding School merupakan salah satu sekolah penyelenggara program sekolah berbasis boarding yang telah diadvokasi bersama 111 sekolah berbasis boarding lainnya se-Indonesia, dengan menjadikan Al Wildan Islamic Boarding School sebagai penyelenggara program-program sekolahnya (Purwoko, 2021).

Upaya memadukan pendidikan sekolah formal khususnya SMP-SMA dengan boarding akan menghasilkan sistem pendidikan yang lebih kuat dan lengkap. Namun beberapa hal yang menjadi pertanyaan penulis, bagaimana sekolah tersebut dapat mempertahankan eksistensinya menghadapi persaingan global dan bagaimana pula pengelolaan serta penerapan manajemennya. Dari uraian di atas penulis merasa tertarik untuk menyusun penelitian dengan judul Implementasi Manajemen Sekolah Berbasis Boarding dalam Meningkatkan Mutu Pendidikan di Al Wildan Islamic Boarding School Tangerang.

\section{TINJAUAN PUSTAKA}

\section{Konsep Pendidikan Islam di Indonesia}

a. Definisi Pendidikan Islam

Secara etimologis pendidikan diterjemahkan ke dalam bahasa Arab yaitu Tarbiyah dengan kata kerja Robba yang berarti mengasuh, mendidik, dan memelihara (Darajat, 1996). Pendidikan Islam merupakan pendidikan yang lebih banyak ditujukan kepada perbaikan sikap mental yang akan terwujud dalam amal perbuatan, baik bagi keperluan diri sendiri maupun orang lain yang bersifat teoritis dan praktis (Darajat, 1996). Ahmad D. Marimba mengemukakan bahwa pendidikan Islam adalah bimbingan secara sadar oleh pendidik terhadap perkembangan jasmani dan rohani peserta didik menuju terbentuknya kepribadian yang utama (insan kamil) (AlRasyidin, 2005).

b. Fungsi Pendidikan Islam

1) Mengembangkan wawasan yang tepat dan benar mengenai jati diri manusia, alam sekitar, dan kemaha besaran Allah S.W.T., sehingga tumbuh kreativitas yang benar (Achmadi, 1987). 
2) Menyucikan diri dari syirik dan berbagai perilaku yang dapat mencemari fitrah kemanusiaan, dengan cara menginternalisasikan nilai-nilai insani dan ilahi melalui pengajaran Al-Qur'an dan As-Sunnah pada peserta didik (Achmadi, 1987).

3) Mengembangkan ilmu pengetahuan untuk menopang dan memajukan kehidupan, baik secara individual maupun sosial masyarakat (Achmadi, 1987).

c. Boarding Sebagai Lembaga Pendidikan Islam di Indonesia

1) Definisi Boarding

Istilah boarding (pesantren) berasal dari kata santri yang mendapat imbuhan pedan akhiran an. Namun sesuai dengan hukum tata bahasa Indonesia, fonemena ini berubah membentuk kata boarding (Feisal, 1995). Dalam Kamus Besar Bahasa Indonesia, boarding diartikan sebagai asrama santri atau tempat murid-murid belajar mengaji (Tim Penyusun KBBI, 2003).

2) Tipe atau Macam-macam Boarding

i) Boarding Salaf (Tradisional)

Merupakan boarding yang diasuh oleh kyai dan tetap mempertahankan materi pengajaran kitab kitab klasik Islam atau kitab dengan huruf arab gundul (DEPAG RI, 1989)

ii) Boarding Khalaf (Modern)

Merupakan boarding yang menerapkan sistem pendidikan formal seperti madrasah maupun sekolah serta memasukkan pengetahuan umum dan bahasa nonarab dalam kurikulum (DEPAG RI, 1989).

iii) Boarding Komprehensif atau Campuran

Merupakan boarding yang sistem pendidikan dan pengajarannya gabungan antara tradisional dan modern (DEPAG RI, 1989). Artinya dalam kurikulum terdapat pembelajaran kitab kuning namun secara regular sistem persekolahan terus di kembangkan.

3) Metode Pengajaran

i) Metode sorogan, yaitu santri membaca sebuah kitab dihadapan kyai, kemudian jika ada kesalahan dalam bacaan maka langsung dibenarkan oleh kyai (DEPAG RI, 1989).

ii) Metode Bandongan atau Wetonan, yaitu kyai membacakan, menerjemahkan, dan menerangkan teks-teks kitab yang berbahasa arab tanpa harakat (gundul). Sementara itu, para santri memberikan harakat, memberikan makna di bawah kata, dan keterangan-keterangan lain yang dianggap perlu.

4) Pola Kepemimpinan Boarding

Di dalam boarding, santri maupun ustadz sangat dipengaruhi oleh perilaku kyai. Gaya kepemimpinan di boarding mempunyai ciri paternalistik dan free rein leadership, dimana pemimpin bersifat pasif sebagai seorang bapak yang memberikan kesempatan kepada anaknya untuk berkreasi, tetapi juga bersifat otoriter yang memberikan kata-kata final untuk memutuskan apakah karya peserta didiknya dapat diteruskan atau tidak (Haryanto, 2012).

Dari uraian di atas dapat dipahami bahwa kyai menggunakan pola pendekatan situasional. Kyai tidak hanya mengajarkan kitab namun mendidik, memberikan 
nasihat, serta menjadi tempat konsultasi masalah, bahkan berfungsi pula sebagai orang tua sekaligus guru yang bisa ditemui tanpa batas waktu.

\section{Manajemen Pada Lembaga Pendidikan di Indonesia}

a. Definisi Manajemen

Manajemen adalah proses perencanaan, pengorganisasian, pengarahan, dan pengawasan yang dilakukan oleh suatu lembaga agar mencapai tujuan organisasi yang telah ditetapkan. Selain itu, manajemen juga dapat diartikan sebagai proses penggunaan sumber daya secara efektif untuk mencapai sasaran (Tim Penyusun KBBI, 2003).

b. Fungsi Manajemen

1) Planning (perencanaan)

2) Organizing (pengorganisasian)

3) Actuating (penggerakkan)

4) Controlling (pengawasan)

5) Evaluating (evaluasi) (Rohani, 1991).

c. Sekolah Berbasis Boarding

Menjamurnya sekolah umum berbasis pembinaan Islam (boarding) akhir-akhir ini mendapat respon dari pemerintah. Secara nasional, menurut data Kemendikbud, sampai tahun 2012 tercatat 1402 sekolah di Indonesia yang bergabung dalam sekolah berbasis boarding (SBB). Sekolah berbasis boarding (SBB) merupakan model sekolah yang mengintegrasikan keunggulan sistem pendidikan di sekolah dan keunggulan sistem pendidikan di boarding (Purwoko, 2021).

Tujuan dan hasil yang diharapkan dalam sekolah berbasis boarding yaitu: pertama, mengembangkan model pendidikan unggulan yang integratif dan komprehensif dalam peningkatan mutu sumber daya manusia Indonesia. Kedua, mengembangkan model pendidikan yang berorientasi pada pencapaian keunggulan komparatif (comparative advantages) dan keunggulan kompetitif (competitive advantages) dalam menghadapi persaingan global. Ketiga, meningkatkan mutu sumber daya manusia yang memiliki keseimbangan intelektual (fikr), skill (amal) dan moralitas (zikr \& qalb) (Purwoko, 2021).

Selain itu, SBB juga memiliki prinsip-prinsip dasar yaitu, mengintegrasikan empat belas kemampuan intelektual (IQ, SQ, dan EQ), berwawasan keunggulan lokal, regional, maupun internasional, tidak diskriminatif, kesadaran atas hak asasi manusia, penguasaan kitab kuning, pengembangan pendidikan kecakapan hidup, proses pembelajaran terpadu (IMTAQ dan IPTEK), dan perlakuan khusus terhadap peserta didik yang memiliki kemampuan khusus. SBB diharapkan memberikan kontribusi positif dalam memperbaiki moral para remaja. Pilihan memadukan sistem sekolah dan boarding ini diambil setelah melihat banyak orang tua yang belum mampu mendidik anak-anaknya secara tepat. Sekolah berbasis boarding bisa menjadi salah satu jawaban persoalanpersoalan karakter dan pendidikan moralitas.

Manajemen pada sekolah berbasis boarding menggunakan perpaduan antara manajemen yang diterapkan di sekolah dengan manajemen yang diterapkan di boarding. Sekolah berbasis boarding (SBB) merupakan model boarding school atau sekolah berasrama. Para siswa mengikuti pendidikan reguler dari pagi hingga sore 
hari di sekolah, kemudian dilanjutkan dengan pendidikan agama atau pendidikan nilai-nilai khusus hingga malam hari di boarding. Selama 24 jam peserta didik berada dalam pengawasan dan bimbingan para guru. Di sekolah peserta didik dituntut untuk menguasai pengetahuan umum dan teknologi, sedangkan di boarding peserta didik dituntut untuk menguasai pendidikan agama.

Pelajaran dan pendidikan di sekolah berbasis boarding (SBB) harus mencakup hal-hal sebagai berikut:

1) Pendidikan dan pengajaran agama

2) Pendidikan dan pengajaran ilmu pengetahuan umum

3) Pendidikan keterampilan dan sosial

4) Pendidikan dan pengajaran kesenian

5) Pendidikan dan pengajaran akhlak

\section{Total Quality Management Dalam Konteks Pendidikan}

a. Definisi Total Quality Management

Merupakan sistem manajemen yang mengangkat kualitas sebagai strategi usaha dan berorientasi pada kepuasan pelanggan dengan melibatkan seluruh anggota organisasi (Nasution, 2005). Tujuannya adalah untuk menjamin bahwa pelanggan puas terhadap barang dan jasa yang diberikan, serta menjamin bahwa tidak ada pihak yang dirugikan (Sallis, 2011).

Jadi, dapat disimpulkan bahwa Total Quality Management (TQM) merupakan teori ilmu manajemen yang mengarahkan pimpinan organisasi dan personilnya untuk melakukan program perbaikan mutu secara berkesinambungan yang terfokus pada pencapaian kepuasan para pelanggan.

b. Syarat TQM dalam Pendidikan

Ada beberapa syarat yang harus dilakukan untuk mengimplementasikan TQM dalam pendidikan, diantaranya:

1) Komitmen manajemen puncak Kepala sekolah harus mencurahkan tenaga, pikiran, dan waktu untuk implementasi TQM. Dengan keterlibatan manajeman puncak (kepala sekolah), pelaksanaan TQM akan dapat digerakkan, diawasi, dan dievaluasi oleh kepala sekolah secara langsung (Nasution, 2005).

2) Komitmen atas sumber daya yang dibutuhkan Segala sesuatu memang memerlukan biaya, namun biaya tersebut harus digunakan seefisien mungkin, misalnya untuk melakukan pelatihan bagi elemen sekolah dan konsultan (Nasution, 2005).

3) Organization Wide Steering

Committee Steering committee ini dipimpin oleh kepala sekolah dan anggotanya dari warga sekolah misal, waka kurikulum, kesiswaan, humas, bagian saranaprasarana, dan kepala administrasi sekolah (Nasution, 2005).

Steering committee ini berfungsi untuk menentukan cara implementasi TQM serta mengawasi pelaksanaannya.

a) Perencanaan dan publikasi

Perencanaan merupakan faktor utama yang harus dilakukan sebelum melaksanakan suatu kegiatan. Untuk mengimplementasikan TQM perlu dipersiapkan hal-hal sebagai berikut: 
b) Membuat visi sekolah

Visi adalah pandangan jangka panjang yang merupakan perpaduan langkah strategis dan sesuatu yang dicita-citakan oleh lembaga atau sekolah (Diana, 2003). Visi dapat dijabarkan dalam indikator dan tujuan sekolah.

c) Membuat sasaran dan tujuan umum

Sasaran maupun tujuan umum harus sesuai dengan visi yang telah di buat secara bersama. Sasaran hendaknya mencerminkan kegiatan akademik dan non akademik yang akan dicapai oleh sekolah.

d) Rencana implementasi TQM Implementasi TQM yang dibuat harus diarahkan untuk visi, misi, dan tujuan sekolah.

e) Program penghargaan dan pengakuan prestasi Sekolah harus memberikan penghargaan terhadap siswa atau tenaga pendidik yang telah berprestasi, misal memberikan beasiswa, promosi jabatan, dan kenaikan gaji.

f) Pendekatan publisitas Seluruh elemen sekolah harus mengetahui apa yang sedang terjadi dalam lingkungan sekolah. Oleh karena itu, informasi yang ada harus selalu disampaikan agar elemen sekolah dapat memahami dan mendukung keputusan manajemen.

g) Pembentukan infrastruktur pendukung dan perbaikan berkesinambungan. Faktor lain dalam implementasi TQM adalah pembentukan infrastruktur pendukung dan perbaikan berkesinambungan antara visi, tujuan, program pengakuan, penghargaan atas prestasi, dan komunikasi (Nasution, 2005).

\section{METODE PENELITIAN}

Jenis penelitian yang digunakan oleh penulis merupakan penelitian kualitatif dengan menggunakan metode deskriptif yang bertujuan untuk mengumpulkan data dan menguraikannya secara menyeluruh serta teliti sesuai dengan persoalan yang akan dipecahkan (Iqbal, 2002).

Istilah kualitatif sendiri mengacu pada pengertian yang luas, yaitu penelitian yang menghasilkan hal-hal deskriptif, diantaranya berupa kata-kata dan perilaku orang-orang yang dapat diobservasi, baik secara lisan maupun tulisan faktual serta menganalisis data yang ada dalam penelitian (Moleong, 2001). Adapun pendekatan yang digunakan dalam penelitian ini adalah pendekatan deskriptif kualitatif. Pendekatan tersebut pada hakekatnya adalah kegiatan mengamati orang, melakukan wawancara, serta berusaha memaknai kebiasaan dan perilaku yang berhubungan dengan penelitian (Moleong, 2001). Selain itu, penelitian ini juga dapat digolongkan sebagai penelitian lapangan (field research) karena peneliti langsung menggali data di lapangan.

\section{PEMBAHASAN}

\section{Manajemen Al Wildan Islamic Boarding School}

A. Manajemen Kurikulum

Berdasarkan hasil wawancara dengan salah satu musyrifah yang bernama NR tanggal 14 Januari 2021,

"Al Wildan Islamic Boarding School menggunakan model pembelajaran terstruktur, Moving Class, serta Out door activity. Selanjutnya instrumen 
penilaian berbentuk test serta non test. Laporan hasil pembelajaran atau raport disampaikan kepada orang tua/wali setiap 1 semester sekali bersamaan dengan raport sekolah".

Peneliti juga mengambil sumber dari keterangan di atas di buku panduan Al Wildan Islamic Boarding School Tahun 2021. Selain itu, setelah melakukan pengamatan, peneliti mendapatkan hasil seperti pembelajaran memang dilakukan secara terstruktur, Moving Class, serta Out door activity.

B. Manajemen Kepegawaian

Bersumber dari hasil wawancara dengan bagian kepegawaian yang bernama SY tanggal 14 Januari 2021 dipaparkan bahwa:

"Prosedur pengelolaan pegawai baru di boarding meliputi rekrutmen wali kamar atau musyrif dan musyrifah dan selanjutnya kemantapan pegawai. Jadi, prosedur pengelolaan pegawai telah disepakati dan dilakukan bersama-sama antara pihak sekolah dengan pihak boarding melalui rapat-rapat koordinasi".

Setelah melihat di buku panduan dan diperkuat dengan pengamatan, peneliti menyesuaikan pernyataan SY tersebut yaitu,

"Kepegawaian di Al Wildan Islamic Boarding School meliputi mudir boarding, sekretaris boarding, bendahara boarding, bagian kebersihan, bagian keamanan, bagian ketakmiran, bagian kebahasaan, serta wali kamar."

C. Manajemen Kesiswaan

Berdasarkan hasil wawancara dengan salah satu musyrifah yang bernama NR pada tanggal 14 Januari 2021 berkata bahwa:

"Siswa yang sekolah di Al Wildan Islamic Boarding School wajib tinggal di Al Wildan Islamic Boarding School dan mengikuti semua kegiatan boarding. Jadi, selain menjadi siswa juga akan menjadi santri. Selain itu, terdapat pula registrasi bagi santri baru dan heregistrasi bagi santri lama".

Pernyataan tersebut diperkuat dengan pengamatan yang dilakukan peneliti bahwa setelah KBM di sekolah, para siswa kembali ke boarding untuk mengikuti kegiatan keboardingan. Di buku panduan juga dijabarkan mengenai jadwal aktivitas harian yang dilakukan oleh santri. Hal tersebut sebagai bukti bahwa siswa Al Wildan Islamic Boarding School harus tinggal di boarding.

D. Manajemen Keuangan

Berdasarkan buku panduan Al Wildan Islamic Boarding School Tahun 2021,

"Manajemen keuangan di boarding terfokus pada keuangan santri. Misalnya santri diperbolehkan membawa uang sebesar Rp. $20.000,00$ per pekan, santri harus menitipkan uangnya kepada wali kamar atau bendahara boarding jika melebihi jumlah yang ditetapkan, dan santri diwajibkan membayar infaq sebesar 2000,- melalui bendahara ketika meminta izin keluar kompleks tidak pada jadwal yang ditentukan".

Pernyataan di atas diperkuat dengan hasil wawancara dengan salah satu santri yang bernama BR, bahwa:

"Santri diperbolehkan membawa uang sebesar Rp. $20.000,00$ per pekan dan diwajibkan membayar infaq sebesar 2000,- melalui bendahara ketika meminta izin keluar kompleks tidak pada jadwal yang ditentukan". 
E. Manajemen Humas Berdasarkan wawancara dengan bagian humas yang bernama HA pada tanggal 14 Januari 2021, memaparkan bahwa

"Pola hubungan orang tua dengan boarding meliputi hubungan rutin dan hubungan insidental. Hubungan rutin berupa pertemuan ketika pengambilan raport setiap semester dan hubungan insidental berupa konsultasi dengan mudir boarding, wali kamar, serta Home Visit".

HA menambahkan:

"Bahwa Al Wildan Islamic Boarding School memiliki prosedur kunjungan boarding diantaranya kunjungan diutamakan pada jam-jam kosong, orang tua/wali santri berbusana Islami ketika berkunjung ke kompleks boarding, dan orang tua/wali lawan jenis dilarang masuk ke kamar putera-puterinya."

Pernyataan tersebut diperkuat dengan keterangan di buku panduan Al Wildan Islamic Boarding School Tahun 2021.

"Kunjungan diutamakan pada jam-jam kosong, orang tua/wali santri berbusana Islami ketika berkunjung ke kompleks boarding, dan orang tua/wali lawan jenis dilarang masuk ke kamar putera-puterinya".

F. Manajemen Sarana Prasarana Boarding

Pengelolaan sarana prasarana di boarding disesuaikan dengan pengelolaan sarana prasarana disekolah. Berdasarkan observasi peneliti pada tanggal 14 Januari 2021, sarana prasarana di Al Wildan Islamic Boarding School meliputi masjid, poliklinik, koperasi, kantor yayasan, asrama santri, rumah pengasuh, kamar ustadz/ustadzah, lapangan olahraga, kamar mandi, dapur, dan area jemuran pakaian. Pernyataan tersebut diperkuat dengan wawancara RI bahwa:

"Sarana prasarana di Al Wildan Islamic Boarding School meliputi masjid, poliklinik, koperasi, kantor yayasan, asrama santri, rumah pengasuh, kamar ustadz/ustadzah, lapangan olahraga, kamar mandi, dapur, dan area jemuran pakaian".

G. Manajemen Layanan Khusus

Berdasarkan observasi peneliti pada tanggal 14 Januari 2021, Al Wildan Islamic Boarding School memiliki layanan khusus seperti disediakannya koperasi untuk memenuhi kebutuhan pribadi santri, santri yang sakit dapat berobat ke poliklinik boarding, santri dapat berkonsultasi dan bimbingan konseling dengan musyrif/musyrifah apabila mengalami masalah atau kesulitan, dan santri mendapatkan jaminan keamanan selama berada di boarding. Pernyataan tersebut diperkuat dengan wawancara RD yang menyatakan bahwa : "Al Wildan memiliki layanan khusus seperti poliklinik dan BK serta keamanan."

Penerapan TQM Di Al Wildan Islamic Boarding School

Pada tanggal 14 Januari 2021, PW selaku kepala sekolah menjelaskan mengenai mutu sekolah yaitu: "Standart maksimal yang mencerminkan kualitas atau prestasi yang diharapkan dan dicita-citakan. Standart ini harus berupa segala sesuatu yang bisa diukur dan di evaluasi. Selanjutnya, TQM merupakan manajemen yang berorientasi pada mutu atau kwalitas untuk memuaskan pelanggan (siswa, orangtua, guru, karyawan, dan warga sekolah lainnya)." 
Kemudian berkenaan dengan komitmen untuk memuaskan pelanggan, kepala sekolah di Al Wildan Islamic Boarding School menyatakan: "Saya secara langsung senantiasa mengawasi, mengarahkan, dan mengevaluasi segala kegiatan baik di dalam sekolah maupun di luar sekolah sesuai dengan komitmen yang telah disepakati bersama".

Berdasarkan hasil wawancara dengan PW pada tanggal 14 Januari 2021, "Pihak Al Wildan Islamic Boarding School Tahun Pelajaran 2021/2021 telah memiliki komitmen sumber daya yang dibutuhkan, misalnya dana sekolah digunakan untuk pemberdayaan siswa, perbaikan sarana prasarana, dan peningkatan kinerja guru".

PW menetapkan sebuah keputusan bersama melalui pendekatan ilmiah dengan cara melakukan identifikasi masalah, prioritas pemecahan dan analisa, mengadakan rapat insidental, rapat pekanan, rapat pimpinan, serta berkoordinasi dengan dinas pendidikan. Selain itu, keputusan diambil dengan memperhatikan materi putusan, ruang lingkup putusan, dan dengan siapa keputusan diambil.

Masih berdasarkan hasil wawancara dengan PW pada tanggal 14 Januari 2021, "Al Wildan Islamic Boarding School rutin memberikan penghargaan atau reward. Hal ini bertujuan untuk memacu dan memotivasi guru, karyawan, serta peserta didik supaya lebih meningkatkan prestasi dan kinerja. Pemberian penghargaan atau reward sesuai dengan kesepakatan dan musyawarah bersama".

Sekolah juga menerapkan pendekatan publisitas dengan seluruh warga sekolah. Jadi, seluruh elemen di Al Wildan Islamic Boarding School selalu mengetahui apa yang sedang terjadi dalam lingkungan sekolah. Informasi selalu diberikan supaya elemen sekolah dapat memahami dan mendukung keputusan manajemen. Jadi pendekatan publisitas sudah diterapkan dengan baik di Al Wildan Islamic Boarding School.

Al Wildan Islamic Boarding School secara bertahap telah melakukan perbaikan berkesinambungan. Seperti perbaikan sarana prasarana, perbaikan program sekolah, perbaikan kinerja guru serta prestasi siswa. Semuanya bertujuan untuk meningkatkan mutu atau kwalitas di sekolah tersebut.

Masyarakat termotivasi untuk menyekolahkan anaknya di Al Wildan Islamic Boarding School meningkat. Sistem manajemen yang mengangkat kualitas sebagai strategi usaha dan berorientasi pada kepuasan pelanggan dengan melibatkan seluruh anggota organisasi telah menjadikan Al Wildan Islamic Boarding School sebagai institusi yang berkualitas. Pihak Al Wildan Islamic Boarding School juga mengadakan pelatihan-pelatihan untuk menunjang prestasi dan kualitas kerja meliputi pelatihan tentang administrasi guru, pelatihan tentang manajemen pengelolaan kelas, dsb. Program unggulan sekolah meliputi prestasi akademis (nilai UN), terinternalisasinya kepribadian islami, menguasai bahasa, IPTEK, serta unggul dalam al-Qur'an. PW menggunakan model kepemimpinan secara kooperatif, kolektivitas, dan lebih banyak mendengar. PW selalu mengajak semua stakeholder, komite, yayasan, untuk duduk bersama memberikan ide/gagasan serta bekerjasama dalam implementasinya.

Sebagai sekolah berbasis boarding, Al Wildan Islamic Boarding School menggunakan dua kurikulum yaitu, kurikulum pendidikan nasional dan kurikulum keboardingan (ulum syar'i). Masing-masing kurikulum tersebut memiliki program kegiatan dan mata pelajaran. Siswa belajar di sekolah dari pagi hingga siang, kemudian sore hingga malam belajar di 
boarding. Pengelolaan kurikulum yang baik harus memenuhi empat tahapan yaitu, perencanaan, pengorganisasian, pelaksanaan, dan pengendalian (Mulyasa, 2011).

Sekalah Menengah Pertama Islam Terpadu (SMP IT) Al Wildan Islamic Boarding School sudah memenuhi empat tahapan tersebut seperti diadakannya raker guru, penyusunan dan pengelompokan konten mapel, pembagian jadwal pelajaran, pelaksanaan programprogram yang telah disusun, serta waka kurikulum melakukan controlling monitoring, dan sebagainya. Penyusunan program kegiatan, penentuan model pembelajaran dan materi, penilaian, serta evaluasi dilakukan pula pada boarding.

Menurut Mulyasa (2011) manajemen kepegawaian mencakup perencanaan pegawai, pengadaan pegawai, pembinaan dan pengembangan pegawai, pemberhentian pegawai, kompensasi, dan penilaian. Manajemen kepegawaian di Al Wildan Islamic Boarding School telah memenuhi cakupan tersebut seperti rekrutmen guru, kemantapan pegawai, adanya usul tentang cuti, adanya ketentuan pemberhentian pegawai, pembinaan SDM yang dilakukan unit dan evaluasi secara bertahap.

Selanjutnya diadakan pula pembagian pegawai yang bertugas di boarding dan menduduki posisi sebagai mudir boarding, sekretaris, bendahara, bagian kebersihan, keamanan, bagian ketakmiran, bagian kebahasaan, dan wali kamar. Jadi, prosedur pengelolaan pegawai telah disepakati dan dilakukan bersama-sama antara pihak sekolah dengan pihak boarding melalui rapat-rapat koordinasi.

\section{Kesiswaan}

Menurut (Mulyasa, 2011), manajemen kesiswaan adalah penataan dan pengaturan kegiatan yang berhubungan dengan peserta didik mulai dari awal pendaftaran sampai peserta didik tersebut lulus. Pengelolaan peserta didik di Al Wildan Islamic Boarding School telah berjalan dengan baik. Hal tersebut dibuktikan dengan adanya SPO (Standar Prosedur Operasional) yang mengatur PPDB, registrasi bagi siswa baru, herregistrasi bagi siswa lama, pengaturan kegiatan rutin siswa, tata tertib, dan data beasiswa.

Selanjutnya peserta didik yang telah diterima di Al Wildan Islamic Boarding School diwajibkan untuk tinggal dan mengikuti semua program pembelajaran dan kegiatan di boarding. Jadi, selain menjadi siswa juga akan menjadi santri. Boarding memiliki prosedur perizinan bagi santri yang ingin meninggalkan agenda boarding. Selain itu, boarding juga mengatur prosedur perpulangan bulanan, tata tertib, sanksi, dan penghargaan. Jadi, pengelolaan santri mempunyai kesamaan dengan pengelolaan siswa. Seperti yang telah dijelaskan di manajemen kurikulum, pelaporan kemajuan belajar santri disampaikan melalui raport.

\section{Keuangan}

Sumber dana dalam proses pendidikan dapat dikelompokkan menjadi empat belas yaitu, pemerintah/yayasan, orangtua/wali siswa, dan masyarakat. SMP IT Al Wildan telah melakukan pengelolaan keuangan yang baik. Sumber dana berasal dari orangtua siswa berupa SPP, infaq pembangunan, sumbangan, dan daftar ulang. Selain itu, pihak sekolah juga mengadakan program tabungan siswa yang berupa tabungan wajib, sukarela, dan bulanan. Keuangan digunakan untuk gaji, perbaikan sarana prasarana, dan operasional. Semuanya dilakukan secara terbuka dan transparan. Inti dari manajemen keuangan adalah pencapaian efisiensi dan efektivitas (Mulyasa, 2011). SMP IT Al wildan telah menerapkan pencapaian tersebut. Sistem pembayaran dapat dilakukan secara langsung dengan datang ke sekolah 
maupun melalui transfer. Selanjutnya, pengelolaan keuangan di boarding hanya terfokus pada keuangan santri. Seperti santri hanya diperbolehkan membawa uang Rp. 20.000/pekan. Uang yang melebihi jumlah yang telah ditetapkan dapat dititipkan kepada wali kamar dan diwajibkan membayar infaq ketika meminta izin keluar kompleks.

Berdasarkan keterangan diatas, dapat dilihat bahwa manajemen keuangan di Al Wildan Islamic Boarding School terkoordinir dengan baik. Hal tersebut tidak lepas dari RAPBPP yang dilaksanakan pada setiap awal tahun oleh pihak boarding.

\section{Kehumasan}

Hubungan sekolah dengan orangtua/wali murid dan masyarakat pada hakekatnya merupakan suatu sarana untuk membina dan mengembangkan pribadi murid di sekolah (Mulyasa, 2011). Hal tersebut terlihat pada pola hubungan pihak SMP IT Al Wildan dengan orangtua/wali murid. Hubungan rutin dan insidental seperti pertemuan pada saat pengambilan raport, home visit, dan konsultasi dengan guru BK atau kepala sekolah dapat mengembangkan sekaligus memantau kepribadian siswa. Selanjutnya, kegiatan lain yang bersifat internal dan eksternal dapat mempererat hubungan baik serta mengembangkan wawasan bagi warga sekolah dan masyarakat sekitar.

Selain itu, kunjungan orang tua ke sekolah memiliki prosedur atau aturan yang telah ditentukan oleh pihak sekolah. Hal tersebut dilakukan agar pembelajaran yang sedang berlangsung tidak terganggu terutama bagi siswa yang bersangkutan. Manajemen humas boarding juga mengadakan hubungan rutin dan insidental terhadap orang tua santri. Namun, jenis kegiatan humas yang sering diadakan adalah kegiatan yang berhubungan dengan keboardingan seperti pengajian dan khataman. Prosedur kunjungan orang tua ke boarding mempunyai persamaan dan perbedaan dengan sekolah. Misalnya, kunjungan diutamakan pada jam-jam kosong (tidak sedang pelajaran atau kegiatan definitif). Sedangkan contoh perbedaannya adalah orang tua dapat menghubungi anaknya via telepon ketika berada di boarding. Sedangkan ketika di sekolah tidak diperbolehkan.

\section{Sarana Prasarana}

Salah satu unsur pendidikan yang tidak kalah penting adalah sarana prasarana. Seringkali proses belajar mengajar terganggu karena fasilitas yang kurang memadai. Hal ini tentunya bisa berdampak pula pada menurunnya semangat murid dan guru dalam proses belajar mengajar. Al Wildan Islamic Boarding School telah memiliki sarana prasarana yang memadai seperti Ruang kelas, lab IPA, lab bahasa, lab komputer, perpustakaan, UKS, ruang ICT, ruang BK, ruang guru, ruang TU, ruang OSIS, ruang kepala sekolah, ruang direksi, WC guru, WC siswa, mushola, gudang, nuris mart, gapuro, lapangan, lapangan voli, dan taman. Kegiatan pengelolaan sarana prasarana meliputi kegiatan perencanaan, pengadaan, pengawasan, inventarisasi, dan penataan (Mulyasa, 2011). Berdasarkan keterangan tersebut Al Wildan Islamic Boarding School telah melakukan pengelolaan dengan baik seperti pengadaan kartu inventaris yang diberikan kepada setiap wali kelas untuk mendata barangbarang, pengadaan barang baru pengganti barang yang rusak, penataan taman, dan pengawasan. Selanjutnya, sarana prasarana yang ada di boarding pun cukup memadai seperti masjid, poliklinik, koperasi, kantor yayasan, asrama santri, rumah pengasuh, kamar ustadz/ustadzah, lapangan olahraga, kamar mandi, dapur, dan area jemur pakaian. 


\section{Layanan Khusus}

Manajemen layanan khusus meliputi perpustakaan, kesehatan, dan keamanan (Mulyasa, 2011). SMP IT Al wildan telah melaksanakan layanan khusus tersebut dengan baik seperti pengadaan UKS, BK, perpustakaan, serta adanya pengamanan di sekolah. Masingmasing layanan memiliki fungsi dan prosedur yang ditetapkan oleh sekolah. Selanjutnya layanan khusus yang ada di boarding berupa BK, poliklinik, koperasi, dan keamanan.

\section{Upaya Peningkatan Total Quality Management}

Upaya Peningkatan Mutu Sekolah

Membahas peningkatan total quality management di Al Wildan Islamic Boarding School tidak bisa lepas dari pembahasan kurikulum, tenaga pendidik, tenaga kependidikan, kegiatan belajar mengajar (KBM), sarana prasarana, dan keuangan. Al Wildan Islamic Boarding School saat ini telah mengembangkan kurikulum tingkat satuan pendidikan (KTSP) ditambah dengan kurikulum keboardingan (ulum syar'i). Dalam melaksanakan proses pembelajaran, sekolah selalu menekankan optimalisasi ranah kognitif, afektif, dan psikomotor. Selain itu, sekolah juga berupaya mengoptimalkan peran orang tua dan masyarakat dalam proses pengembangan sekolah dan pembelajaran.

Salah satu tujuan dari TQM adalah merespon keinginan pelanggan. Untuk meningkatkan mutu layanan sekolah harus lebih dulu mengenali siapa pelanggan sekolah, jasa apa yang ditawarkan kepada pelanggan, dan bagaimana ukuran layanan bermutu. Menjawab pertanyaan tersebut tidaklah mudah sebab sekolah bukan pabrik yang menghasilkan suatu produk tertentu. Pelanggan sekolah dapat dibedakan menjadi dua, yaitu pelanggan luar dan pelanggan dalam. Pelanggan luar terdiri dari siswa, orang tua, pemerintah/yayasan, dan masyarakat pengguna lulusan. Sedangkan guru serta karyawan disebut pelanggan dalam. Upaya untuk meningkatkan mutu layanan yang telah dilakukan $\mathrm{Al}$ Wildan Islamic Boarding School adalah:

1) Penggunaan dana seoptimal mungkin. Misal untuk operasional, perbaikan sarana prasarana, peningkatan kinerja guru, dan sebagainya.

2) Program penghargaan dan pengakuan prestasi, kegiatan ekstrakurikuler, program terproyek dan program akademis

3) Meningkatkan profesionalisme guru melalui pelatihan dan seminar

4) Adanya layanan khusus yang disediakan sekolah misal BK dan UKS

5) Adanya hubungan internal dan eksternal antara sekolah dengan pelanggan

6) Layanan pimpinan puncak yang senantiasa mengawasi, mengarahkan, dan mengevaluasi segala kegiatan baik di dalam sekolah maupun di luar sekolah

7) Memiliki visi, misi, dan tujuan yang jelas untuk kemajuan sekolah

8) Adanya pendekatan yang melibatkan seluruh anggota sekolah.

Selanjutnya, Al Wildan Islamic Boarding School menggunakan empat teknik atau cara TQM dalam menetapkan manajemen peningkatan mutu yaitu: school review, benchmarking, quality assurance, dan quality control.

School review adalah proses yang mengharuskan seluruh komponen lembaga pendidikan bekerjasama dengan berbagai pihak yang memiliki keterkaitan misalnya orang tua dan tenaga professional untuk mengevaluasi keefektifan kebijakan lembaga pendidikan, program dan pelaksanaannya, serta mutu lulusannya. Dengan metode ini, kita 
dapat membeberkan kelemahan, kekuatan, prestasi lembaga pendidikan dan memberikan rekomendasi untuk pengembangan lembaga pendidikan di masa mendatang.

Benchmarking merupakan kegiatan untuk menetapkan standar, baik proses maupun hasil yang akan dicapai dalam suatu periode tertentu. Dengan demikian, standar tersebut direfleksikan dalam realitas yang ada.

Quality assurance merupakan konsep yang mengandung jaminan bahwa proses yang berlangsung dilaksanakan sesuai dengan standar dan prosedur yang telah ditetapkan. Dengan demikian, out put yang dihasilkan pun juga sesuai dengan standar.

Quality control merupakan sistem untuk mendeteksi terjadinya penyimpangan out put yang tidak sesuai dengan standar. Sistem ini menuntut adanya indikator yang pasti dan jelas.

\section{Peningkatan Mutu Di Al Wildan Islamic Boarding School}

Untuk menghasilkan institusi yang berkualitas dan output yang unggul maka diperlukan strategi khusus agar sekolah memiliki daya saing dan tetap survive. Itu pula yang coba diterapkan di Al Wildan Islamic Boarding School. Dari usaha-usaha tersebut dapat dilihat hasilnya sebagai berikut:

1) Prestasi akademik :

a) Juara I ujian nasional sekolah swasta tingkat Kabupaten Tangerang

b) Juara II ujian nasional sekolah negeri/swasta tingkat Kabupaten Tangerang

2) Prestasi non akademik : Telah memperoleh 140 tropi kejuaraan tingkat kabupaten dan propinsi yang meliputi juara penelitian ilmiah (penyulingan air, mengukur kadar air dalam susu, mengubah sampah menjadi tenaga listrik dan BBM).

Berdasarkan prestasi-prestasi di atas, motivasi masyarakat untuk menyekolahkan anaknya di Al Wildan Islamic Boarding School meningkat. Sistem manajemen yang mengangkat kualitas sebagai strategi usaha dan berorientasi pada kepuasan pelanggan dengan melibatkan seluruh anggota organisasi telah menjadikan Al Wildan Islamic Boarding School sebagai institusi yang berkualitas.

Kelebihan Dan Kekurangan Sekolah Berbasis Boarding

1) Keunggulan sekolah berbasis boarding

a) Interaksi antar siswa dengan guru bisa berjalan secara intensif serta memudahkan kontrol terhadap kegiatan siswa.

b) Pendidikan SBB dapat membentuk peserta didik yang berjiwa religius, memiliki intelektual tinggi, skill, dan moralitas yang baik

c) Dengan sistem 24 jam atau sistem sepanjang hari (full-day eduactinal system), SBB akan menjadi incaran para orang tua yang sibuk dan tidak mempunyai waktu cukup untuk memberikan perhatian serta kontrol kepada putra-putrinya setelah pulang dari sekolah/madrasah

d) SBB dinilai mampu membentengi para siswa dari pengaruh-pengaruh negatif arus globalisasi yang menghadirkan budaya Barat

e) Konsep one for all lebih dipercaya orang tua karena memberikan layanan pendidikan pada putera-puterinya yang meliputi pendidikan agama, pendidikan umum, dan pendidikan kecakapan hidup. 
f) Lulusan SBB lebih mampu menempatkan posisinya dalam keberagaman status sosial yang berada dalam masyarakat.

g) SBB mampu memadukan sistem pendidikan modern dan tradisional.

2) Kelemahan Sekolah Berbasis Boarding

a) Secara konseptual, belum ada teori komprehensif mengenai bagaimana mengelola sistem pendidikan dengan berlandaskan pada nilai-nilai boarding

b) Pada prinsipnya mengupayakan manajemen pendidikan berbasis boarding merupakan sebuah usaha yang tidak mudah, apalagi harus mencari formulasi yang dapat memuaskan segala pihak yang berkepentingan dengan dunia Pendidikan

c) Sering terjadi tumpang tindih atau pengulangan pelajaran antara kurikulum pendidikan formal dan kurikulum boarding

d) Dualisme manajerial, yaitu kepala sekolah dan mudir boarding. Meskipun telah dibagi bidang kerjanya, namun terkadang terjadi silang pendapat. Kebijakan kepala sekolah tidak sejalan dengan kebijakan mudir boarding. Hal tersebut akan menghambat kemajuan sekolah dan boarding terkait.

\section{KESIMPULAN}

Manajemen pada sekolah berbasis boarding (SBB) menggunakan perpaduan antara manajemen yang diterapkan di sekolah dengan manajemen yang diterapkan di boarding. Manajemen sendiri merupakan proses perencanaan, pengorganisasian, pengarahan, dan pengawasan yang dilakukan oleh suatu lembaga. Manajemen sekolah dan manajemen boarding dibedakan menjadi tujuh macam yaitu : manajemen kurikulum, kepegawaian, kesiswaan, keuangan, sarana prasarana, humas, dan manajemen layanan khusus. Selanjutnya kurikulum yang diterapkan di Al Wildan Islamic Boarding School adalah kurikulum tingkat satuan pendidikan (KTSP) ditambah dengan kurikulum ulum syar'i (keboardingan). Kurikulum dikelola oleh waka kurikulum dan waka kurikulum membawahi beberapa bagian. Manajemennya meliputi Raker guru, penyusunan programprogram, controlling, monitoring, dan evaluasi. Selanjutnya, manajemen kepegawaian di Al Wildan Islamic Boarding School meliputi prosedur penerimaan pegawai baru, diantaranya rekrutmen guru, kemantapan pegawai, pembagian pegawai, penentuan gaji, evaluasi pegawai, dan pembinaan pegawai. Selain itu, bagian kepegawaian juga menangani perihal cuti dan pemberhentian pegawai. Selanjutnya, manajemen kesiswaan meliputi PPDB, daftar ulang (registrasi) bagi siswa baru, dan herregistrasi bagi siswa lama. Pengelolaan kesiswaan juga mencakup kegiatan rutin siswa di sekolah, tata tertib siswa, dan perihal prestasi siswa. Kemudian, manajemen keuangan sekolah mencakup sistem pembayaran SPP serta tabungan siswa. Siswa dianjurkan memiliki tabungan wajib, sukarela, dan bulanan. Pembayaran SPP pun dilakukan pada awal bulan antara tanggal 1- 10. Dana yang telah terkumpul digunakan untuk perbaikan sarana prasarana, operasional, dan gaji. SMP IT Al Wildan selalu mengadakan pertemuan rutin dengan orang tua siswa ketika pengambilan raport. Hubungan insidental berupa home visit dan konsultasi dengan kepala sekolah atau guru BK pun dilakukan oleh kedua pihak. Kegiatan-kegiatan humas dilaksanakan secara internal dan eksternal. Al Wildan Islamic Boarding School juga memiliki layanan khusus berupa UKS, BK, dan perpustakaan. Masing-masing memiliki prosedur pengelolaan kegiatan. Selanjutnya, prosedur pengelolaan sarana prasarana meliputi pemberian kartu inventaris ruangan kepada setiap wali kelas kemudian dilakukan pendataan 
barang-barang serta pengadaan barang-barang baru. Manajemen kurikulum di Al Wildan Islamic Boarding School tidak jauh berbeda dengan manajemen di sekolah. Bagian kurikulum secara rutin mengadakan Rapat kerja untuk menyusun program-program keboardingan, melakukan controlling, monitoring, dan evaluasi. Model pembelajaran dilakukan secara terstruktur, moving class, dan out door activity. Kegiatan penilaiannya pun berbentuk test dan non test. Selanjutnya, bagian kepegawaian meliputi mudir boarding, wali kamar, ketakmiran, keamanan dan kebersihan, serta sekretaris dan keuangan. Pembagian posisi tersebut dilakukan oleh pihak Al Wildan Islamic Boarding School. Kemudian pengelolaan bagian kesiswaan memiliki prosedur yang sama dengan prosedur sekolah. Begitu pula dengan humas, sarana prasarana, dan layanan khusus boarding dilaksanakan sejalan dengan sekolah. Upaya untuk meningkatkan mutu pendidikan yang telah dilakukan Al Wildan Islamic Boarding School adalah pertama, penggunaan dana seoptimal mungkin. Misal untuk operasional, perbaikan sarana prasarana, peningkatan kinerja guru, dan sebagainya. Kedua, pengadaan program penghargaan dan pengakuan prestasi, kegiatan ekstrakurikuler, program terproyek dan program akademis. Ketiga, meningkatkan profesionalisme guru melalui pelatihan dan seminar. Keempat, adanya layanan khusus yang disediakan sekolah misal BK dan UKS. Kelima, adanya hubungan internal dan eksternal antara sekolah dengan pelanggan. Keenam. Layanan pimpinan puncak yang senantiasa mengawasi, mengarahkan, dan mengevaluasi segala kegiatan baik di dalam sekolah maupun di luar sekolah. Ketujuh. Memiliki visi, misi, dan tujuan yang jelas untuk kemajuan sekolah. Kedelapan. Adanya pendekatan yang melibatkan seluruh anggota sekolah. Upayaupaya tersebut telah membuahkan hasil seperti prestasi akademik dan prestasi non akademik. Peningkatan mutu terlihat dari motivasi masyarakat untuk menyekolahkan anaknya di $\mathrm{Al}$ Wildan Islamic Boarding School.

\section{SARAN}

1. SBB telah memberikan kontribusi positif dalam memperbaiki moral para remaja. Maka dari itu, pemerintah terkait harus lebih memperhatikan perkembangan SBB.

2. Pihak sekolah dan boarding harus lebih memperhatikan konten pelajaran untuk peserta didik. Pemisahan antara kurikulum pendidikan formal dan keboardingan harus jelas dan terperinci.

3. Kepala sekolah dan mudir boarding serta antar unit harus meningkatkan kerja sama atau komunikasi melalui pertemuan dan rapat-rapat koordinasi demi kemajuan bersama.

4. Manajemen sekolah dan manajemen boarding merupakan satu kesatuan yang pelaksanaannya harus tetap sejalan.

5. TQM dalam dunia pendidikan bisa dijadikan sebagai langkah alternatif menuju akselerasi mutu pendidikan sehingga sudah saatnya nilai-nilai dalam TQM diterapkan secara komprehensif untuk menghasilkan lulusan yang berkualitas. 


\section{DAFTAR PUSTAKA}

Ahmadi, Djauzak. (1996). Peningkatan Mutu Pendidikan Sebagai Sarana Pembangunan Bangsa. Jakarta: Balai Pustaka.

Al-Rasyidin. (2005). Filsafat Pendidikan Islam. Jakarta: Ciputat Press.

Amin, H. (2010). Efektifitas Total Quality Managemen Melalui system Manajemen Mutu ISO. Makalah Rangkuman Tesis disampaikan pada seminar TQM UIN Sunan Kalijaga Yogyakarta.

Darajat, Zakiah. (1996). Ilmu Pendidikan Islam. Jakarta: Bumi Aksara.

Departemen Pendidikan Nasional. (1989). Kamus Besar Bahasa Indonesia. Jakarta: Balai Pustaka. Cetakan kedua.

Feisal, Amir. (1995). Reorientasi Pendidikan Islam. Jakarta: Gema Insani Press.

Haryanto, Sugeng. (2012). Persepsi Santri Terhadap Perilaku Kepemimpinan Kyai Di Boarding. Jakarta: Kementerian Agama RI.

Hamidi, C.A. (2019). Management Model Oriented to Custemer Satisfaction (TQM) in Gontor Islamic Boarding School (Study Case in Gontor Kampus7). Educan: Jurnal Pendidikan Islam, 3(1): 166-188

Ilham, R. N., Erlina, K. A. F., Silalahi, A. S., Saputra, J., \& Albra, W. (2019). Investigation of the bitcoin effects on the country revenues via virtual tax transactions for purchasing management. Int. J Sup. Chain. Mgt Vol, 8(6), 737.

Iqbal, Hasan. (2002). Pokok-Pokok Materi Metode Penelitian Dan Aplikasinya. Jakarta: Ghalia Indonesia.

Moleong, Lexy J. (2001). Metodologi Penelitian Kualitatif. Bandung: PT. Remaja Rosda Karya.

Mulyasa. (2011). Manajemen Berbasis Sekolah. Bandung: PT. Remaja Rosda Karya.

Muhith. (2018). Quality Culture Of Islamic Boarding School. International Journal of Research-Granthalayah, 6(10), 25-37

Nasution, Nur. (2005). Manajemen Mutu Terpadu (Total Quality Management). Bogor: Ghalia Indonesia.

Purwoko. (2021). Panduan Al Wildan Islamic Boarding School Tahun 2021. Tengaran: Nuris Press.

Sallis, Edward. (2010). Manajemen Mutu Terpadu Pendidikan. Jogjakarta: IRCisD.

Sabda, Syaifuddin. (2006). Model Kurikulum Terpadu IPTEK dan IMTAQ. Ciputat: Quantum Teaching.

Siradj, Sa'id Agiel. (1999). Boarding Masa Depan. (wacana Pemberdayaan dan Transformasi Boarding). Bandung: Pustaka Hidayah.

Rieny, (2021). Manajemen Keuangan Boarding, (http://rienytugas.blogspot.com/2021/06/manajemen-keuangan-boarding.html).

Suhardi, didik. 2021. Peran SMP Berbasis Boarding Sebagai Upaya Penanaman Pendidikan

Karakter Kepada Generasi Bangsa, dalam

(http://download.portalgaruda.org/article.php?article=6615\&val=4146).

ST Maryam, R. A., Sumartono, E., \& Dwi Orbaningsih, R. (2020). GLOBAL FINANCIAL CRISIS MANAGEMENT BY HUMAN RESOURCE MANAGEMENT. Journal of Critical Reviews, 7(1), 287-290. 
Tim Penyusun. (2014). Boarding dan Madrasah Diniyah (Pertumbuhan Dan Perkembangannya). Jakarta: DEPAG RI.

Tjiptono, Fandy \& Anastasia Diana. (2014). Total Quality M.anagement. Yogyakarta: Andi Offset. Cetakan 10. 